\title{
Evidence of the association of BIN1 and PICALM with the AD risk in contrasting European populations
}

Jean-Charles Lambert ${ }^{1,2,3}$, Diana Zelenika ${ }^{4}$, Mikko Hiltunen ${ }^{5}$, Vincent Chouraki ${ }^{1,2,3}$, Onofre Combarros $^{6}$, Maria J Bullido ${ }^{7}$, Gloria Tognoni ${ }^{8}$, Nathalie Fiévet ${ }^{1,2}$, Anne Boland ${ }^{4}$, Beatrice Arosio $^{9}$, Elicer Coto $^{10}$, Maria Del Zompo ${ }^{11}$, Ignacio Mateo ${ }^{6}$, Ana Frank-Garcia ${ }^{12}$, Seppo Helisalmi ${ }^{5}$, Elisa Porcellini ${ }^{13}$, Alberto Pilotto ${ }^{14}$, Paola Forti ${ }^{15}$, Raffaele Ferri ${ }^{16}$, Marc Delepine ${ }^{4}$, Elio Scarpini ${ }^{17}$, Gabriele Siciliano ${ }^{8}$, Vincenzo Solfrizzi ${ }^{18}$, Sandro Sorbi ${ }^{19}$, Gianfranco Spalletta $^{20}$, Giovanni Ravaglia ${ }^{15}$, Fernando Valdivieso ${ }^{7}$, Victoria Alvarez ${ }^{10}$, Paolo Bosco ${ }^{16}$, Michelangelo Mancuso ${ }^{8}$, Francesco Panza ${ }^{18}$, Benedetta Nacmias ${ }^{19}$, Paola Bossù ${ }^{20}$, Paola Piccardi $^{17}$, Giorgio Annoni ${ }^{21}$, Davide Seripa ${ }^{14}$, Daniela Galimberti ${ }^{17}$, Federico Licastro ${ }^{13}$, Mark Lathrop $^{4,22}$, Hilkka Soininen ${ }^{5}$, Philippe Amouyel ${ }^{1,2,3,23}$.

1. INSERM U744, F-59019 Lille, France

2. Institut Pasteur de Lille, F-59019, Lille, France

3. Université de Lille Nord de France, F-59000 Lille, France

4. Centre National de Genotypage, Institut Genomique, Commissariat à l'Énergie Atomique, Evry, France

5. Department of Neurology, Kuopio University and University Hospital, 70211, Kuopio, Finland

6. Neurology Service and CIBERNED, "Marqués de Valdecilla" University Hospital (University of Cantabria), Santander, Spain.

7. Centro de Biologia Molecular Severo Ochoa (UAM-CSIC) and CIBERNED, Universidad Autonoma, Cantoblanco, S-28049, Madrid, Spain

8. Department of Neuroscience, Neurological Clinic, University of Pisa, I-56100, Italy

9. Department of Internal Medicine, Fondazione Policlinico IRCCS, Milan Italy

10. Genetic Molecular Unit, Hospital Universitario Central de Asturias, 33006-Oviedo, Spain

11. Section of Clinical Pharmacology, Department of Neuroscience, University of Cagliari, Italy

12. Servicio de Neurologia, Hospital Universitario La Paz (UAM) and CIBERNED, 28034 Madrid, Spain

13. Department of Experimental Pathology, School of Medicine, University of Bologna, Italy

14. Geriatric Unit \& Gerontology-Geriatric Research Laboratory, Department of Medical Science, IRCCS Casa Sollievo della Sofferenza, San Giovanni Rotondo , I-71013, Italy 
15. Department of Internal Medicine Cardiology and Hepatology, University Hospital S. Orsola-Malpighi, Bologna, Italy

16. IRCCS Oasi Maria SS, 94018 Troina, Italy

17. Dept. of Neurological Sciences, Dino Ferrari Centre, University of Milan, IRCCS Ospedale Maggiore Policlinico, Milan, Italy

18. Department of Geriatrics, Centre for Aging Brain, Memory Unit, University of Bari, Policlinico, 70124 Bari, Italy

19. Department of Neurological and Psychiatric Sciences, 50134 Florence, Italy

20. Department of Clinical and Behavioural Neurology, IRCCS Santa Lucia Foundation, 00179 Roma - Italy

21. Department of Clinical Medicine and Prevention, University of Milano-Bicocca, Monza Italy

22. Fondation Jean Dausset-CEPH, Paris, France

23. CHR\&U de Lille, France

Address correspondence to:

Jean-Charles Lambert

Unité INSERM 744, Institut Pasteur de Lille

BP 245,1, rue du professeur Calmette

F-59019 Lille cedex, France

Tel.: +33 (0)3 20877391

Fax: +33 (0)3 20877894

e-mail: jean-charles.lambert@pasteur-lille.fr 


\begin{abstract}
Recent genome-wide association studies have identified five loci (BIN1, CLU, CR1, EXOC3L2 and PICALM) as genetic determinants of Alzheimer's disease (AD). We attempted to confirm the association between these genes and the $A D$ risk in three contrasting European populations (from Finland, Italy and Spain). Since CLU and CR1 had already been analyzed in these populations, we restricted our investigation to BIN1, EXO2CL3 and PICALM. In a total of 2,816 AD cases and 2,706 controls, we unambiguously replicated the association of rs744373 (for BIN1) and rs541458 (for PICALM) polymorphisms with the AD risk $\left(O R=1.26,95 \% \mathrm{Cl}\right.$ [1.15-1.38], $p=2.9 \times 10^{-7}$, and $\mathrm{OR}=0.80,95 \% \mathrm{Cl}$ [0.74-0.88], $\mathrm{p}=4.6 \times 10^{-}$ ${ }^{7}$, respectively). In a meta-analysis, rs597668 (EXOC3L2) was also associated with the AD risk, albeit to a lesser extent $\left(\mathrm{OR}=1.19,95 \% \mathrm{Cl}[1.06-1.32], \mathrm{p}=2.0 \times 10^{-3}\right)$. However, this signal did not appear to be independent of $A P O E$.

In conclusion, we confirmed that BIN1 and PICALM are genetic determinants of $A D$, whereas the potential involvement of EXOC3L2 requires further investigation.
\end{abstract}




\section{Introduction}

Although Alzheimer's disease (AD) is the most common cause of dementia in the elderly, its aetiology is still not fully understood. The characterization of causative factors is thus important for better defining the pathophysiological processes involved. In this context, the identification of genes involved in monogenic forms of $A D$ has significantly contributed to our knowledge of the disease mechanisms (Bettens, 2010). In contrast, the characterization of genetic factors involved in the common forms of $A D$ (i.e. lacking classical Mendelian inheritance) has encountered significant difficulties; the apolipoprotein E (APOE) gene is the only globally valid genetic determinant of $A D$ to have been unambiguously identified in 15 years of intensive research (Lambert, 2007).

However, as with other multifactorial diseases, this systematic inability to detect new genetic determinants has prompted more comprehensive investigations using genome-wide association studies (GWASs). We and others performed three large GWASs in this field and reported that the CLU (clusterin), PICALM (phosphatidylinositol binding clathrin assembly protein), CR1 (complement component [3b/4b] receptor 1), BIN1 (bridging integrator 1) and EXOC3L2 (exocyst complex component 3-like 2) loci were associated with the AD risk (Harold, 2009; Lambert, 2009; Seshadri, 2010).

To help to clarify the relevance of these genes as genetic determinants of $A D$, we analyzed their associations in contrasting European populations from Finland $(n=1,123)$, Italy $(n=2,811)$ and Spain $(n=1,588)$. Since CLU and CR1 have been already studied in these populations (Lambert, 2009), we only tested single-nucleotide polymorphisms (SNPs) within PICALM, BIN1 and EXOC3L2.

\section{Materials and Methods}

All clinical diagnoses of probable AD were established according to the DSM-III-R and NINCDS-ADRDA criteria. Controls were defined as subjects not meeting the DMS-III-R dementia criteria and with intact cognitive functions (MMS $>25$ ). Written, informed consent was obtained from study participants or, for those with substantial cognitive impairment, from a caregiver, legal guardian, or other proxy. The study protocols for all populations were reviewed and approved by the appropriate independent ethics committees in each country. Information on age and gender in the cases and controls included in the study are shown in Table 1. Samples with missing age or gender data were excluded, yielding a total of 2,816 $A D$ cases and 2,706 controls.

Genotyping for the SNPs (rs744373 in BIN1, rs597668 in EXOC3L2 and rs541458 in PICALM) was performed with a Taqman system (Applied Biosystems). The primer and probe sequences are available on request. In order to avoid bias, cases and controls were randomly mixed when genotyping and the laboratory personnel were blinded to case/control 
status. The genotyping success rate was at least $95 \%$ and no departure from HardyWeinberg equilibrium was observed for the markers (Table 2).

We undertook logistic regression analyses in each country (Finland, Italy and Spain) using an additive genetic model which took account of age, gender, disease status and (when necessary) centre. All analyses were performed with SAS software (release 9.1, SAS Institute, Cary, NC, USA). We then used inverse-variance weighting (also known as fixedeffects meta-analysis) with adjustments for age and gender for the overall effect assessment, using Review Manager software (release 5.0). Interactions between BIN1, EXOC3L2, PICALM and APOE \&4 polymorphisms were tested in logistic regression models adjusted for age, gender and (when necessary) centre. We again used inverse-variance weighting, with adjustments for age and gender for assessment of the overall interaction. Linkage disequilibrium was assessed using Haploview software.

\section{Results}

In each data set, we evaluated the association of $A D$ with the rs744373, rs597668 and rs541458 SNPs within the BIN1, EXOC3L2 and PICALM loci, respectively. Even though the detected associations were not always statistically significant in all data sets, they were comparable in direction in the three different European populations. When the data sets were examined in a meta-analysis, we found strong evidence of associations for BIN1 (OR=1.26, $\left.\mathrm{p}=2.9 \times 10^{-7}\right), \operatorname{PICALM}\left(\mathrm{OR}=0.80, \mathrm{p}=4.7 \times 10^{-7}\right)$ and, to a lesser extent, EXOC3L2 (OR=1.19, $\mathrm{p}=2.0 \times 10^{-3}$ ) (Table 3).

We also searched for significant interactions between these three loci and APOE but failed to identify any in either the independent data sets or in the meta-analysis. We nevertheless reevaluated the association of the BIN1, PICALM and EXOC3L2 SNPS with the AD risk by adjusting for age, gender and the presence of at least one APOE $\varepsilon 4$ allele. Whereas the BIN1 and PICALM associations were not modified (data not shown), we found no evidence of an association of $E X O C 3 L 2$ with the $A D$ risk after adjustment of the data sets taken individually (Finland, OR=0.91, $\mathrm{p}=4.2 \times 10^{-1}$; Italy, $\mathrm{OR}=0.99, \mathrm{p}=8.9 \times 10^{-1}$; Spain, $\mathrm{OR}=1.06$, $\left.\mathrm{p}=6.2 \times 10^{-1}\right)$ or in the meta-analysis $\left(\mathrm{OR}=0.98, \mathrm{p}=7.8 \times 10^{-1}\right)$.

\section{Discussion}

Over recent months, our picture of the genetics of AD has changed greatly and suggests that most of the genuine genetic determinants of this disease will differ from those suspected before the advent of the GWASs (Laumet, 2010; Sleegers, 2010). By looking at contrasting European populations of $A D$ cases and controls in which the associations of CLU and CR1 with $A D$ had already replicated (Lambert, 2009), we confirmed the association of PICALM and BIN1 with the AD risk. The ORs are comparable in direction and magnitude with those 
originally reported. The association of PICALM with the AD risk has been already replicated in several large data sets (Carrasquillo, 2010; Corneveaux, 2010; Jun, in press; Kamboh, in press; Seshadri, 2010). Using the ORs reported in the AlzGene database (http://www.alzgene.org) (Bertram, 2007) and by including our new data, a meta-analysis unambiguously showed that this gene is a genuine risk factor for $A D(O R=0.87,95 \% \mathrm{Cl}[0.84$ 0.90], $p=5.5 \times 10^{-18}, p$ for heterogeneity=0.27).

To the best of our knowledge, our study is the first to have replicated the association of the BIN1 and EXOC3L2 loci with the AD risk. The meta-analysis of our data and those gathered by Seshadri et al. strongly supported the involvement of the BIN1 gene in AD (OR=1.16, $95 \% \mathrm{Cl}\left[1.12-1.21, \mathrm{p}=1.6 \times 10^{-15}, \mathrm{p}\right.$ for heterogeneity=0.14). However, in contrast to Seshadri et al.'s report, we were unable to show that the EXOC3L2 signal was independent of the $A P O E$ locus. Surprisingly, and even though this gene locus is close to $A P O E$, we did not detect linkage disequilibrium between the APOE $\varepsilon 4$ allele and the rs597668 SNP (D'=0.36 and $r^{2}=0.075$ at most, in the Finland data set). This locus thus deserves more attention, in order to confirm or refute its association with the AD risk.

In conclusion, we unambiguously replicated the association of the PICALM and BIN1 loci (both of which code for proteins involved in endocytosis and clathrin-mediated synaptic vessel formation (Harel, 2008; Wigge, 1997)) with the AD risk in contrasting European populations. In order to determine the exact implication of BIN1 and PICALM in AD, it is now essential to develop major, systematic, ambitious efforts in sequencing and genotyping (even for rare variants), together with replication in large, independent populations and functional analyses of intermediate phenotypes.

\section{ACKNOWLEDGMENTS}

The work was made possible by the generous participation of the control subjects, the patients and their families.

Finish sample collection: financial support for this project was provided by the Health Research Council of the Academy of Finland, EVO grant 5772708 from Kuopio University Hospital and the Nordic Centre of Excellence in Neurodegeneration.

Italian sample collections: the Bologna site $(F L)$ obtained funds from the Italian Ministry of Research and Universities and from the Carimonte Foundation. The Florence site was funded by a grant from the Italian Ministry of Health (RFPS-2006-7-334858). The Milan site was funded by a grant from the Monzino Foundation. We are grateful for the expert contribution from Mr Carmelo Romano.

Spanish sample collection: the Madrid site (MB) was funded by grants from the Ministerio de Educación y Ciencia and the Ministerio de Sanidad y Consumo (Instituto de Salud Carlos III), and an institutional grant from the Fundación Ramón Areces to the CBMSO. We thank I. 
Sastre and Dr A Martínez-García for the preparation and quality control of the DNA collection and Drs. P. Gil and P. Coria for their cooperation in the case/control recruitment. We are grateful to the Asociación de Familiares de Alzheimer de Madrid (AFAL) for continuous encouragement and assistance. 


\section{Reference:}

Bertram, L., McQueen, M.B., Mullin, K., Blacker, D., Tanzi, R.E. 2007. Systematic meta-analyses of Alzheimer disease genetic association studies: the AlzGene database. Nat Genet. 39, 17-23.

Bettens, K., Sleegers, K., Van Broeckhoven, C. 2010. Current status on Alzheimer disease molecular genetics: from past, to present, to future. Hum Mol Genet. 19, R4-R11.

Carrasquillo, M.M., Belbin, O., Hunter, T.A., Ma, L., Bisceglio, G.D., Zou, F., Crook, J.E., Pankratz, V.S., Dickson, D.W., Graff-Radford, N.R., Petersen, R.C., Morgan, K., Younkin, S.G. 2010. Replication of CLU, CR1, and PICALM associations with alzheimer disease. Ach Neurol. 67, 961-964.

Corneveaux, J.J., Myers, A.J., Allen, A.N., Pruzin, J.J., Ramirez, M., Engel, A., Nalls, M.A., Chen, K., Lee, W., Chewning, K., Villa, S.E., Meechoovet, H.B., Gerber, J.D., Frost, D., Benson, H.L., O'Reilly, S., Chibnik, L.B., Shulman, J.M., Singleton, A.B., Craig, D.W., Van Keuren-Jensen, K.R., Dunckley, T., Bennett, D.A., De Jager, P.L., Heward, C., Hardy, J., Reiman, E.M., Huentelman, M.J. 2010. Association of CR1, CLU and PICALM with Alzheimer's disease in a cohort of clinically characterized and neuropathologically verified individuals. Hum Mol Genet. 19, 3295-3301.

Harel, A., Wu, F., Mattson, M.P., Morris, C.M., Yao, P.J. Evidence for CALM in directing VAMP2 trafficking. Traffic. 9, 417-429.

Harold, D., Abraham, R., Hollingworth, P., Sims, R., Gerrish, A., Hamshere, M.L., Pahwa, J.S., Moskvina, V., Dowzell, K., Williams, A., Jones, N., Thomas, C., Stretton, A., Morgan, A.R., Lovestone, S., Powell, J., Proitsi, P., Lupton, M.K., Brayne, C., Rubinsztein, D.C., Gill, M., Lawlor, B., Lynch, A., Morgan, K., Brown, K.S., Passmore, P.A., Craig, D., McGuinness, B., Todd, S., Holmes, C., Mann, D., Smith, A.D., Love, S., Kehoe, P.G., Hardy, J., Mead, S., Fox, N., Rossor, M., Collinge, J., Maier, W., Jessen, F., Schürmann, B., van den Bussche, H., Heuser, I., Kornhuber, J., Wiltfang, J., Dichgans, M., Frölich, L., Hampel, H., Hüll, M., Rujescu, D., Goate, A.M., Kauwe, J.S., Cruchaga, C., Nowotny, P., Morris, J.C., Mayo, K., Sleegers, K., Bettens, K., Engelborghs, S., De Deyn, P.P., Van Broeckhoven, C., Livingston, G., Bass, N.J., Gurling, H., McQuillin, A., Gwilliam, R., Deloukas, P., AlChalabi, A., Shaw, C.E., Tsolaki, M., Singleton, A.B., Guerreiro, R., Mühleisen, T.W., Nöthen, M.M., Moebus, S., Jöckel, K.H., Klopp, N., Wichmann, H.E., Carrasquillo, M.M., Pankratz, V.S., Younkin, S.G., Holmans, P.A., O'Donovan, M., Owen, M.J., Williams, J. Genome-wide association study identifies variants at CLU and PICALM associated with Alzheimer's disease. Nat Genet. 41, 1088-1093.

Jun, G., Naj, A.C., Beecham, G.W., Wang, L.S., Buros, J., Gallins, P.J., Buxbaum, J.D., Ertekin-Taner, N., Fallin, M.D., Friedland, R., Inzelberg, R., Kramer, P., Rogaeva, E., St George-Hyslop, P., Arnold, S.E., Baldwin, C.T., Barber, R., Beach, T., Bigio, E.H., Bird, T.D., Boxer, A., Burke, J.R., Cairns, N., Carroll, S.L., Chui, H.C., Clark, D.G., Cotman, C.W., Cummings, J.L., Decarli, C., Diaz-Arrastia, R., Dick, M., Dickson, D.W., Ellis, W.G., Fallon, K.B., Farlow, M.R., Ferris, S., Frosch, M.P., Galasko, D.R., Gearing, M., Geschwind, D.H., Ghetti, B., Gilman, S., Giordani, B., Glass, J., Graff-Radford, N.R., Green, R.C., Growdon, J.H., Hamilton, R.L., Harrell, L.E., Head, E., Honig, L.S., Hulette, C.M., Hyman, B.T., Jicha, G.A., Jin, L.W., Johnson, N., Karlawish, J., Karydas, A., Kaye, J.A., Kim, R., Koo, E.H., Kowall, N.W., Lah, J.J., Levey, A.I., Lieberman, A., Lopez, O.L., Mack, W.J., Markesbery, W., Marson, D.C., Martiniuk, F., Masliah, E., McKee, A.C., Mesulam, M., Miller, J.W., Miller, B.L., Miller, C.A., 
Parisi, J.E., Perl, D.P., Peskind, E., Petersen, R.C., Poon, W., Quinn, J.F., Raskind, M., Reisberg, B., Ringman, J.M., Roberson, E.D., Rosenberg, R.N., Sano, M., Schneider, J.A., Schneider, L.S., Seeley, W., Shelanski, M.L., Smith, C.D., Spina, S., Stern, R.A., Tanzi, R.E., Trojanowski, J.Q., Troncoso, J.C., Van Deerlin, V.M., Vinters, H.V., Vonsattel, J.P., Weintraub, S., Welsh-Bohmer, K.A., Woltjer, R.L., Younkin, S.G., Cantwell, L.B., Dombroski, B.A., Saykin, A.J., Reiman, E.M., Bennett, D.A., Morris, J.C., Lunetta, K.L., Martin, E.R., Montine, T.J., Goate, A.M., Blacker, D., Tsuang, D.W., Beekly, D., Cupples, L.A., Hakonarson, H., Kukull, W., Foroud, T.M., Haines, J., Mayeux, R., Farrer, L.A., Pericak-Vance, M.A., Schellenberg, G.D. 2010. Meta-analysis Confirms CR1, CLU, and PICALM as Alzheimer Disease Risk Loci and Reveals Interactions With APOE Genotypes. Arch Neurol. Sep 3. [Epub ahead of print]

Kamboh, M.I., Minster, R.L., Demirci, F.Y., Ganguli, M., Dekosky, S.T., Lopez, O.L., Barmada, M.M. 2010. Association of CLU and PICALM variants with Alzheimer's disease. Neurobiol Aging. 2010 Jun 4. [Epub ahead of print]

Lambert, J.C., Amouyel, P. 2000. Genetic heterogeneity of Alzheimer's disease: complexity and advances. Psychoneuroendocrinology. 32, S62-70.

Lambert, J.C., Heath, S., Even, G., Campion, D., Sleegers, K., Hiltunen, M., Combarros, O., Zelenika, D., Bullido, M.J., Tavernier, B., Letenneur, L., Bettens, K., Berr, C., Pasquier, F., Fiévet, N., Barberger-Gateau, P., Engelborghs, S., De Deyn, P., Mateo, I., Franck, A., Helisalmi, S., Porcellini, E., Hanon, O.; European Alzheimer's Disease Initiative Investigators, de Pancorbo, M.M., Lendon, C., Dufouil, C., Jaillard, C., Leveillard, T., Alvarez, V., Bosco, P., Mancuso, M., Panza, F., Nacmias, B., Bossù, P., Piccardi, P., Annoni, G., Seripa, D., Galimberti, D., Hannequin, D., Licastro, F., Soininen, H., Ritchie, K., Blanché, H., Dartigues, J.F., Tzourio, C., Gut, I., Van Broeckhoven, C., Alpérovitch, A., Lathrop, M., Amouyel, P. Genome-wide association study identifies variants at CLU and CR1 associated with Alzheimer's disease. Nat Genet. 41, 1094-1099.

Laumet, G., Chouraki, V., Grenier-Boley, B., Legry, V., Heath, S., Zelenika, D., Fievet, N., Hannequin, D., Delepine, M., Pasquier, F., Hanon, O., Brice, A., Epelbaum, J., Berr, C., Dartigues, J.F., Tzourio, C., Campion, D., Lathrop, M., Bertram, L., Amouyel, P., Lambert, J.C. 2010. Systematic analysis of candidate genes for Alzheimer's disease in a French, genome-wide association study. J Alzheimers Dis. 20, 1181-1188.

Seshadri, S., Fitzpatrick, A.L., Ikram, M.A., DeStefano, A.L., Gudnason, V., Boada, M., Bis, J.C., Smith, A.V., Carassquillo, M.M., Lambert, J.C., Harold, D., Schrijvers, E.M., Ramirez-Lorca, R., Debette, S., Longstreth, W.T. Jr, Janssens, A.C., Pankratz, V.S., Dartigues, J.F., Hollingworth, P., Aspelund, T., Hernandez, I., Beiser, A., Kuller, L.H., Koudstaal, P.J., Dickson, D.W., Tzourio, C., Abraham, R., Antunez, C., Du, Y., Rotter, J.I., Aulchenko, Y.S., Harris, T.B., Petersen, R.C., Berr, C., Owen, M.J., Lopez-Arrieta, J., Varadarajan, B.N., Becker, J.T., Rivadeneira, F., Nalls, M.A., Graff-Radford, N.R., Campion, D., Auerbach, S., Rice, K., Hofman, A., Jonsson, P.V., Schmidt, H., Lathrop, M., Mosley, T.H., Au, R., Psaty, B.M., Uitterlinden, A.G., Farrer, L.A., Lumley, T., Ruiz, A., Williams, J., Amouyel, P., Younkin, S.G., Wolf, P.A., Launer, L.J., Lopez, O.L., van Duijn, C.M., Breteler, M.M.; CHARGE Consortium, GERAD1 Consortium, EADI1 Consortium. Genome-wide analysis of genetic loci associated with Alzheimer disease. JAMA. 2010 May 12;303(18):1832-40.

Sleegers, K., Lambert, J.C., Bertram, L., Cruts, M., Amouyel, P., Van Broeckhoven, C. 2010. The pursuit of susceptibility genes for Alzheimer's disease: progress and prospects. Trends Genet. 26, 84-93. 
Wigge, P., Köhler, K., Vallis, Y., Doyle, C.A., Owen, D., Hunt, S.P., McMahon, H.T. Amphiphysin heterodimers: potential role in clathrin-mediated endocytosis. Mol Biol Cell. 8, 2003-2015. 
Table 1: characteristics of the different case-control studies according to countries

\begin{tabular}{|c|c|c|c|c|c|c|}
\hline & \multicolumn{2}{|c|}{ Finland (1 centre) } & \multicolumn{2}{|c|}{ Italy (10 centres) } & \multicolumn{2}{|c|}{ Spain (3 centres) } \\
\hline & $\mathrm{AD}$ cases & Controls & $\mathrm{AD}$ cases & controls & $\mathrm{AD}$ cases & controls \\
\hline $\mathrm{n}$ & 589 & 541 & 1520 & 1291 & 755 & 833 \\
\hline Mean age & $71.3 \pm 7.4$ & $69.0 \pm 6.4$ & $76.6 \pm 8.7$ & $72.3 \pm 8.9$ & $75.3 \pm 9.3$ & $76.9 \pm 10.9$ \\
\hline Mean age at onset & $71.3 \pm 7.4$ & - & $73.8 \pm 8.8$ & - & $72.5 \pm 9.4$ & - \\
\hline \% male & 32 & 42 & 32 & 45 & 43 & 38 \\
\hline
\end{tabular}


Table 2: Genotype distribution of rs744373, rs597668 and rs541458 in AD cases and controls

\begin{tabular}{|c|c|c|c|c|c|c|}
\hline \multirow{2}{*}{ rs744373 } & \multicolumn{6}{|c|}{ Genotype distribution freq. (n) } \\
\hline & \multicolumn{2}{|c|}{$\mathrm{AA}$} & \multicolumn{2}{|c|}{ AG } & \multicolumn{2}{|c|}{$\mathbf{G G}$} \\
\hline \multicolumn{7}{|l|}{ Finland } \\
\hline Controls (529) & 0.603 & (319) & 0.337 & (178) & 0.060 & (32) \\
\hline \multicolumn{6}{|l|}{ Italy } & (34) \\
\hline Controls (1265) & 0.535 & (677) & 0.399 & (504) & 0.066 & (84) \\
\hline $\begin{array}{l}\text { Cases (1460) } \\
\text { Spain }\end{array}$ & 0.489 & (714) & 0.431 & (629) & 0.080 & (117) \\
\hline Controls (829) & 0.551 & (457) & 0.395 & (327) & 0.054 & (45) \\
\hline Cases (726) & 0.463 & (336) & 0.423 & $(307)$ & 0.114 & (83) \\
\hline \multirow{2}{*}{ rs597668 } & \multicolumn{6}{|c|}{ Genotype distribution freq. $(n)$} \\
\hline & \multicolumn{2}{|c|}{$\mathrm{TT}$} & \multicolumn{2}{|c|}{ TC } & \multicolumn{2}{|c|}{ CC } \\
\hline
\end{tabular}

Finland

Controls (529) $\quad 0.571 \quad$ (302) 0.348 (184) $0.081 \quad$ (43)

$\begin{array}{llllllll}\text { Cases (562) } & 0.471 & \text { (265) } & 0.429 & \text { (241) } & 0.100 & \text { (56) }\end{array}$

Italy

Controls (1268) $0.773 \quad$ (980) $0.210 \quad$ (266) $0.017 \quad$ (22)

$\begin{array}{lllllll}\text { Cases (1457) } & 0.765 & \text { (1115) } & 0.219 & \text { (336) } & 0.140 & \text { (90) }\end{array}$

Spain

Controls (832) $\quad 0.804 \quad$ (669) $0.180 \quad$ (150) $0.016 \quad$ (13)

$\begin{array}{llllllll}\text { Cases } & (727) & 0.769 & \text { (559) } & 0.212 & \text { (54) } & 0.019 & \text { (14) }\end{array}$

\begin{tabular}{cccc}
\multirow{2}{*}{ rs541458 } & \multicolumn{3}{c}{ Genotype distribution freq. $(n)$} \\
\cline { 2 - 4 } & TT & TG
\end{tabular}

Finland

$\begin{array}{lllllll}\text { Controls (521) } & 0.403 & \text { (210) } & 0.430 & \text { (225) } & 0.167 & \text { (86) }\end{array}$

$\begin{array}{llllllll}\text { Cases (561) } & 0.438 & \text { (246) } & 0.437 & \text { (245) } & 0.125 & \text { (70) }\end{array}$

Italy

Controls (1257) $0.439 \quad$ (552) $0.446 \quad$ (561) $0.115 \quad$ (144)

$\begin{array}{llllllll}\text { Cases (1460) } & 0.515 & \text { (752) } & 0.406 & \text { (592) } & 0.080 & \text { (116) }\end{array}$

Spain

Controls (819) $0.492 \quad$ (403) $0.419 \quad$ (343) $0.089 \quad$ (73)

\begin{tabular}{llllllll} 
Cases & $(723)$ & 0.546 & (395) & 0.391 & (283) & 0.062 & (45) \\
\hline
\end{tabular} 
Table 3: Association of rs744373, rs597668 and rs541458 with the AD risk in Finnish, Italian and Spanish case-control studies. (HW, hardy-Weinberg; MAF, minor allele Frequency)

\begin{tabular}{|c|c|c|c|c|c|c|c|c|}
\hline \multirow{2}{*}{$\begin{array}{c}\text { rs744373 } \\
\text { (BIN1) }\end{array}$} & \multicolumn{2}{|c|}{$\mathrm{N}$} & \multicolumn{2}{|c|}{ MAF } & \multirow[t]{2}{*}{ HW } & \multicolumn{2}{|c|}{ Association Test } & \multirow{2}{*}{$\begin{array}{c}\text { APOE interaction } \\
\mathrm{P} \text { value }\end{array}$} \\
\hline & Cases & Controls & Cases & Controls & & OR $(95 \%$ CI $)$ & $P$ value & \\
\hline Finland & 563 & 529 & 0.24 & 0.23 & $2.9 \times 10^{-1}$ & $1.12(0.92-1.37)$ & $2.6 \times 10^{-1}$ & $8.5 \times 10^{-1}$ \\
\hline Italy & 1460 & 1265 & 0.30 & 0.27 & $4.5 \times 10^{-1}$ & $1.22(1.07-1.38)$ & $2.0 \times 10^{-3}$ & $6.6 \times 10^{-1}$ \\
\hline Spain & 726 & 829 & 0.33 & 0.25 & $1.7 \times 10^{-1}$ & $1.43(1.22-1.68)$ & $1.4 \times 10^{-6}$ & $7.3 \times 10^{-1}$ \\
\hline Meta-analysis ${ }^{1}$ & & & & & & $1.26(1.15-1.38)$ & $2.9 \times 10^{-7}$ & $6.8 \times 10^{-1}$ \\
\hline rs597668 & \multicolumn{2}{|c|}{$\mathrm{N}$} & \multicolumn{2}{|c|}{ MAF } & & \multicolumn{2}{|c|}{ Association Test } & APOE interaction \\
\hline (EXO3CL2) & Cases & Controls & Cases & Controls & & OR (95\% CI) & $P$ value & $\mathrm{P}$ value \\
\hline Finland & 562 & 529 & 0.31 & 0.26 & $5.0 \times 10^{-2}$ & $1.38(1.14-1.66)$ & $9.0 \times 10^{-4}$ & $5.9 \times 10^{-1}$ \\
\hline Italy & 1457 & 1268 & 0.13 & 0.12 & $4.2 \times 10^{-1}$ & $1.05(0.89-1.24)$ & $5.7 \times 10^{-1}$ & $6.3 \times 10^{-2}$ \\
\hline Spain & 727 & 832 & 0.13 & 0.11 & $1.8 \times 10^{-1}$ & $1.19(0.96-1.48)$ & $1.1 \times 10^{-1}$ & $7.9 \times 10^{-1}$ \\
\hline Meta-analysis ${ }^{1}$ & & & & & & $1.19(1.06-1.32)$ & $2.0 \times 10^{-3}$ & $1.1 \times 10^{-1}$ \\
\hline rs541458 & \multicolumn{2}{|c|}{$\mathrm{N}$} & \multicolumn{2}{|c|}{ MAF } & & \multicolumn{2}{|c|}{ Association Test } & APOE interaction \\
\hline (PICALM) & Cases & Controls & Cases & Controls & & OR $(95 \% \mathrm{CI})$ & $P$ value & $\mathrm{P}$ value \\
\hline Finland & 561 & 521 & 0.34 & 0.38 & $6.0 \times 10^{-2}$ & $0.85(0.71-1.01)$ & $6.8 \times 10^{-2}$ & $9.0 \times 10^{-1}$ \\
\hline Italy & 1460 & 1257 & 0.30 & 0.26 & $9.4 \times 10^{-1}$ & $0.78(0.69-0.88)$ & $5.1 \times 10^{-5}$ & $6.6 \times 10^{-1}$ \\
\hline Spain & 723 & 819 & 0.26 & 0.30 & $1.0 \times 10^{-1}$ & $0.81(0.69-0.95)$ & $1.1 \times 10^{-2}$ & $7.1 \times 10^{-1}$ \\
\hline Meta-analysis ${ }^{1}$ & & & & & & $0.80(0.74-0.88)$ & $4.6 \times 10^{-7}$ & $9.7 \times 10^{-1}$ \\
\hline
\end{tabular}

${ }^{1}$ inverse-variance weighting with adjustments for age, gender and centre when necessary A fixed effect model was used ( $p$-value for heterogeinity not significant whatever the SNP analysed, $p=0.12$ for BIN1, $p=0,11$ for EXO2CL3 and $p=0.68$ for PICALM) 